\title{
KEABSAHAN NIKAH SIRI DALAM PERSPEKTIF MASLAHAH
}

\author{
Zulham Wahyudani
}

\author{
IAIN Langsa \\ Zoelham679@yahoo.com
}

\begin{abstract}
This study focus on exploring maslahah of the marriage registration for nikah siri. Based on the result, first; the goverment used maslahah approacj to determine the marriage registration as one of the marriage requirements. therefore, the unregistered marriages will be punished as the illegal one. Nowdays, the marriage registration had become the publication to justify the legality of someone's marriage, as well as to protect their right and obligation such as the protection of their offspring, property, life and so on. second, marriage registration cannot be negotiated to be undone by providing legal certainty through the revision of law No. 1 of 1974. This study recomended that every nikah siri should be register to the KUA to obtain their marriage legality from the government.
\end{abstract}

Keywords: Nikah siri, maslahah, marriage administration

Abstrak: Penelitian ini bertujuan untuk mencari kemaslahatan pencatatan terhadap nikah siri. Berdasarkan hasil kajian pertama, pemerintah dengan pendekatan maslahah dapat menetapkan pencatatan sebagai syarat nikah. Sehingga perkawinan yang tidak dicatatkan akan dihukumi ilegal. Pencatatan nikah pada saat ini menjadi publikasi yang dapat membenarkan legalitas nikah seseorang serta untuk melindungi hak dan kewajiban mereka seperti perlindungan terhadap keturunan, harta, jiwa, dan lain-lain. Kedua, pencatatan nikah tidak bisa ditawar lagi untuk dilakukan dengan cara memberikan kepastian hukum legalitas melalui revisi Undangundang No. 1 Tahun 1974. Dalam kajian ini disarankan agar setiap 
pernikahan siri untuk mendaftarkan pernikahannya kepada pihak yang berwenang supaya mendapat legalitas dari pemerintah.

Kata Kunci: nikah siri, maslahah, dan pencatatan nikah.

\section{PENDAHULUAN}

Pernikahan merupakan suatu ikatan antara dua individu yang sebelumnya tidak saling berkait. Pernikahan juga merupakan suatu akad yang menghalalkan pergaulan antara seorang laki-laki dan perempuan yang bukan mahram (Zuhaili, 1989:29), serta menimbulkan hak dan kewajiban antara keduanya. Dalam hukum pernikahan, membina rumah tangga merupakan keinginan semua orang. Hubungan yang harmonis, saling percaya, saling melindungi, dan saling mendukung sangatlah diharapkan.

Di Indonesia banyak terjadi praktek-praktek dari pernikahan, salah satunya nikah siri. Nikah siri dikenal umumnya oleh masyarakat Indonesia sekarang ini ialah pernikahan yang dilakukan dengan memenuhi rukun dan syarat yang ditetapkan agama, tetapi tidak dilakukan di hadapan Pegawai Pencatat Nikah sebagai aparat resmi pemerintah atau perkawinan di mana tidak dicatat di Kantor Urusan Agama bagi yang beragama Islam atau di kantor catatan sipil bagi yang tidak beragama Islam, sehingga tidak mempunyai akta nikah yang dikeluarkan pemerintah.

Persoalan nikah siri telah banyak diteliti dari sudut pandang yang beragam. Pertama dari sudut kajian fiqh klasik (Ma'u, 2016; Khosyi'ah, 2015; Jaya, 2017). Mereka menyimpulkan bahwa nikah siri hukumnya sah namun banyak kemudratannya. Adapun dari sudut pandang dampak sosial terhadap nikah siri ( et al., 2017), (Ma'sum, 2013), (Prihatini, 2009). Mereka menyimpulkan bahwa dampak nikah siri dalam masyarakat sangat buruk seperti hak nafkah, pemeliharaan anak, harta gono-gini, dan tempat tinggal. Begitu juga dari sudut pandang hukum positif di Indonesia dan negara-negara Muslim (Siddik, 2017; Faiza \& Rahman, 2014; Mustika, 2011). Mereka menyimpulkan bahwa undang- 
undang tentang pernikahan ini sudah jauh tertinggal dari negera-negara Muslim lainnya. Namun dari sudut pandang Maslahah masih sedikit yang membahas Sehingga menarik untuk meneliti nikah siri dari sudut kemaslahatan ini.

Menurut Bahasa, kata maslahah berasal dari Bahasa Arab dan telah dibakukan ke dalam Bahasa Indonesia menjadi maslahat, yang berarti mendatangkan kebaikan atau yang membawa kemanfaatan dan menolak kerusakan. Adapun maslahah dari dari sebuah pernikahan dalam hukum positif yaitu Undang-Undang No. 1 Tahun 1974 tentang Perkawinan Pasal 2 ayat (2), disebutkan bahwa setiap perkawinan harus dicatat menurut hukum yang berlaku. Bahkan dalam Kompilasi Hukum Islam (KHI) dinyatakan bahwa pencatatan pernikahan dilakukan oleh Pegawai Pencatat Nikah (PPN) yang dilakukan di hadapan dan di bawah pengawasannya (Instruksi, 1997:15). Pernikahan yang dilakukan di luar pengawasannya tidak mempunyai kekuatan hukum. Sehingga nikah siri dianggap sebagai nikah yang tidak lengkapnya suatu perbuatan hukum karena tidak tercatat secara resmi dalam catatan resmi pemerintah.

Pemerintah Indonesia sudah berupaya untuk menyelesaikan permasalahan ini. Dalam Draf Rancangan Undang-Undang tentang Hukum Materiil Peradilan Agama (RUU HMPA) Bidang Perkawinan disebutkan bahwa setiap orang yang dengan sengaja melangsungkan perkawinan tidak di hadapan pejabat pencatat nikah dipidana dengan ancaman hukuman bervariasi. Mulai dari enam bulan hingga tiga tahun dan denda mulai dari Rp 6 juta hingga Rp 12 juta (Ma'u, 2016: 36). Namun sampai sekarang, RUU HMPA belum juga menjadi undang-undang yang sah guna mencegah permasalahan nikah siri yang semakin lama semakin rumit.

Wacana pemerintah untuk memidanakan pelaku nikah siri dengan mengundang-undangkan pernikahan siri tersebut menemuai pro dan kontra dalam banyak kalangan. Pihak yang mendukung rencana dikeluarkannya RUU ini. mengungkapkan, Adanya RUU tersebut nantinya bisa memberi kemaslahatan bagi 
masyarakat. Namun wacana ini ditolak kalangan yang menolak dan menjelaskan bahwa alasan penolakan tersebut karena nikah siri dalam ajaran Islam sudah sah memenuhi persyaratan. Maka pelaku nikah siri tidak dapat dipidana.

Dengan demikian nikah siri di dalam realita telah menambah daftar praktik diskriminasi yang dilakukan laki-laki (suami) terhadap hak-hak perempuan. Pihak perempuan berpeluang mendapat perlakuan kekerasan dalam rumah tangga (KDRT) dari pernikahan secara siri ini. Adapun proses hukum yang dapat diusahakan adalah pelaku kekerasan dijerat dengan status sebagai seseorang atau orang lain bukan berstatus sebagai suami karena mereka tidak mempunyai bukti ontentik sebagai sepasang suami istri yang sah di mata hukum. Tidak hanya itu, anak-anak juga dapat menjadi korban pernikahan siri yang tidak bertanggung jawab (Engneer, 1994: 151). Seorang ayah dari nikah siri akan mudah melepaskan tanggungjawab terhadap anaknya karena ia tidak terikat secara undang-undang sebagai ayah yang sah. Sehingga nikah siri dapat menjadi praktik yang melanggengkan penindasan terhadap hak-hak perempuan dan anak.

Dalam kajian ini penulis melihat bahwa pelaku nikah siri telah melanggar pencatatan. Karena di Indonesia sebuah pernikahan dipandang sah secara substansif apabila telah memenuhi rukun dan syarat nikah serta pernikahan haruslah dicatat petugas nikah sebagai suatu ketentuan administratif agar mendapatkan kepastian hukum dan terpenuhi hak dan kewajiban antara keduanya. Dengan demikian, pernikahan tidak selesai hanya dengan berlangsungnya akad nikah, melainkan harus juga dicatat.

Persoalan tersebut telah penulis lihat dan telaah di beberapa buku dan karya ilmiah yang lain, serta penulis yakin permasalahan ini merupakan persoalan yang kontemporer dan menarik untuk dikaji dan dibahas dalam sebuah jurnal guna menjawab persoalan keabsahan nikah siri dalam perspektif maslahah. 


\section{PERAN MASLAHAH DALAM PEMERINTAHAN ISLAM}

Secara bahasa, maslahah berarti kebaikan dengan tujuan untuk menghilangkan kerusakan (Manzūr, 1994:156). Di dalam kamus Munjîd, maslahah sebagai sesuatu yang mendatangkan kebaikan yaitu perbuatan-perbuatan manusia yang dapat mendatangkan manfaat kepada diri sendiri serta kaumnya. (al-Yasu'î, tt: 432). lafaz maslahah memiliki dua pengertian:

a. Perbuatan yang mendatangkan kebaikan atau manfaat. Namun, ini adalah pengertian secara majazi karena perbuatan itu sendiri bukanlah manfaat atau mafsadah, tetapi menjadi sebab kepada lahirnya mashlahah atau mafsadah tersebut.

b. Kebaikan itu sendiri. Inilah pengertian mashlahah secara hakiki. Dengan kata lain, mashlahah ialah keadaan baik seperti yang semestinya.

Oleh karena itu, dapat dipahami bahwa mashlahah itu ialah sesuatu yang membawa kepada kebaikan manusia. Karena setiap kebaikan yang dikaitkan dengan manusia dianggap sebagai mashlahah walaupun mashlahah itu kadangkala tidak membawa manfaat sepenuhnya kepada semua manusia. Singkatnya mashlahah adalah segala usaha yang dilakukan untuk mendapatkan kebaikan dan menolak kemudharatan yaitu memelihara dan meraih tujuan-tujuan syara' sekalipun ia bertentangan dengan kehendak individu atau golongan.

Dalam konteks pemerintahan Islam, apabila dilihat antara hubungan rakyat dengan pemimpin adalah berpijak pada dasar mashlahah, menurut Izzudin bin 'Abd al-Salam bahwa seluruh syari'at Islam itu adalah mashlahah sama ada baik dengan cara menolak mafsadah maupun meraih mashlahah yang nyata. Setiap perbuatan manusia itu ada yang membawa kepada kemaslahatan dan ada juga yang membawa kepada mafsadah. Setiap mashlahah itu berkaitan dengan hal kebaikan, manfaat serta akan diperoleh pahala sekiranya dilakukan sebaik mungkin (al-salam, 1990:11). Dari segi aspek syari'at, kemaslahatan dapat dibagi kepada tiga yaitu wajib dilaksanakan, ada yang harus dilaksanakan dan mubah 
dilaksanakan. Sedangkan mafsadah dibagi kepada dua yaitu haram dan makruh dilaksanakan Rohayana, 2008: 155).

Menurut pandangan Al-Ghazali dalam al-Mustasyfā min 'Ilmi al-Ushul, (AlGhazli, tt: 253-259), al-Syatibi dalam kitabnya al-Muwafaqat fi Ushul al-Syari'ah (Al-Syatibi, 1994:8-38) dan Abdul Wahab Khalaf dalam kitab Masādir al-Tasyri' fi ma lā nas fih (al-Khalaf, 1887:50) dalam kriteria kemaslahatan itu dapat disimpulkan seperti berikut:

1. Maslahah harus sesuai dengan maqāsid al-syari'ah.

2. Maslahah harus sesuai dengan dalil-dalil kulli dan qat'i baik dari segi wurūd atau dalālah.

3. Mashlahah haruslah sesuatu yang menyakinkan, didasarkan pada penelitian yang teliti dan cermat, sehingga tidak diragukan lagi untuk mendatangkan manfaat dan menghindari mudarat.

4. Mashlahah yang dapat membawa kemudahan dan tidak mendatangkan kesulitan.

Dapat ditegaskan bahwa menjadi tanggungjawab bagi semua pihak untuk menjaga mashlahah serta menolak segala mafsadah yang tidak ada kepentingan di dunia dan akhirat. Sekiranya dilihat ada mashlahah, maka itu adalah tujuan syara' yang telah tersedia ruang yang luas bagi pemikir dalam menentukan sesuatu hukum tertentu. Ini karena syara' telah menetapkan dasar-dasar dan kaidah-kaidah hukum yang dapat memenuhi keperluan dan mashlahah manusia di setiap zaman dan tempat dengan penggunaan akal untuk menyelesaikan masalah manusia yang senantiasa berubah-ubah. Mashlahah yang menjadi tujuan syara' yang terdapat di dalam perkara baru yang dihadapi oleh manusia itu, dapat dijadikan ukuran dan pertimbangan dalam menentukan hukum serta menguraikan hukum tersebut secara terperinci.

Dengan demikian, secara sederhana mashlaah dapat dinyatakan sebagai meraih semua kebaikan untuk manusia yang diatur oleh pemerintah dengan berdasarkan kemaslahatan serta mencegah semua keburukan yang sesuai dengan 
syari'ah. Syari'at Islam itu tidak lain untuk mewujudkan kemaslahatan manusia dan menolak kemudaratan. Kemaslahatan manusia itu tidak terbatas jumlahnya dan tidak terhingga jumlahnya. la selalu bertambah dan berkembang mengikuti situasi dan kondisi masyarakat.

Pendekatannya dengan al-Qur'an dan Sunnah, para ulama ushul fiqh membagi mashlahah menjadi tiga macam: pertama al-mashlahah al-mu'tabarah, yaitu mashlahah yang langsung disebutkan kemaslahatannya. Kedua al-maslahah al-mulghah, yaitu mashlahah yang tidak dianggap atau ditolak oleh syara'. Sedangkan yang ketiga adalah al-mashlahah al-mursalah, yaitu mashlahah yang tidak disebutkan oleh syara' dan juga tidak ditolak (Asy-Syathibi, tt: 38). Mashlahah ketiga ini tidak mempunyai dasar Nash khusus atau terperinci sebagai sumber pengambilan atau sandaranya, tetapi dapat dikembalikan kepada dalil atau prinsip yang diambil dari ayat atau hadist.

Mashlahah dalam kategori ketiga menjadi perbincangan para ulama ushul, ada yang menerima dan ada juga yang menolaknya. Jumhur ulama, mulai zaman imam mazhab sampai ke zaman al-Ghazali, cenderung tidak menerima hasil istinbath dengan al-mashalih al-mursalah sekiranya tidak didukung oleh Nash yang khusus. Menurut mereka, pertimbangan al-mashlahah al-mursalah tidak dapat diterima karena sama maknanya dengan membuat hukum syara' berdasarkan pertimbangan subjektif. Sedangkan kebanyakan ulama bermazhab Malik dan Hambali menyatakan bahwa mashlahah jenis ketiga ini dapat diterima dalam penalaran untuk penetapan hukum (Abu Bakar, 2011:35).

Secara sederhana dapat disimpulkan bahwa pemeritahan Islam diartikan sebagai ketentuan kebijakan pengurusan masalah kenegaraan oleh pemerintah terhadap rakyatnya yang berdasarkan kemaslahatan sesuai dengan ketentuan syari'ah Islam. 


\section{NIKAH SIRI DALAM PERUNDANG-UNDANGAN DI INDONESIA}

Jika diperhatikan secara teliti, UU No. 1 Tahun 1974 bukanlah UU pertama yang mengatur tentang pencatatan perkawinan bagi Muslim Indonesia. Sebelumnya sudah ada UU No. 22 Tahun 1946, yang mengatur tentang pencatatan nikah, talak dan rujuk. Semula UU ini hanya berlaku untuk daerah Jawa dan Madura, tetapi dengan lahirnya UU No. 32 tahun 1954 yang disahkan pada tanggal 26 oktober 1954, diberlakukan di seluruh Indonesia (Nasution, 2009:333).

Tentang pencatatan perkawinan dalam UU No. 22 tahun 1946 disebutkan, perkawinan diawasi oleh Pegawai Pencatat Nikah. Bagi pasangan yang melakukan perkawinan tanpa pengawasan dari Pegawai Pencatat Nikah dikenakan hukuman karena merupakan suatu pelanggaran. Karena tujuan pencatatan perkawinan agar mendapat kepastian hukun dan ketertiban. Ketika menjelaskan hukuman bagi pasangan yang melakukan perkawinan tanpa pengawasan disebutkan, maksud hukuman bagi pasangan yang melanggar adalah agar aturan administrasi ini diperhatikan, tetapi tidak mengakibatkan batalnya perkawinan. (Nasution, 2009:334) .Dari penjelesan ini sangat tegas terlihat bahwa fungsi pencatatan hanyalah bersifat administrasi bukan syarat sah atau tidaknya perkawinan.

Kemudian dalam UU No. 1 Tahun 1974 yang pelaksanaannya berlaku secara efektif mulai tangal 1 Oktober 1975 tentang pencatatan perkawinan disebutkan Pasal 2 ayat ( 1 dan 2 ) bahwa "tiap-tiap perkawinan dicatat menurut perundangundangan yang berlaku". Sementara pasal lain disebutkan, perkawinan adalah sah apabila dilakukan menurut hukum masing-masing agamanya dan kepercayaannya itu. Sedangkan dalam penjelasan terhadap UU No. 1 Tahun 1974 tentang pencatatan dan sahnya perkawinan disebutkan; "tidak ada perkawinan di luar hukum agama", maksudnya hukum agama termasuk peraturan perundangundangan yang berlaku. Kemudian dalam PP No. 9 Tahun 1975 yang merupakan peraturan tentang pelaksanaan UU No. 1 Tahun 1974, disebutkan bahwa perkawinan bagi penganut Islam dilakukan oleh Pegawai Pencatat Nikah, dengan 
tata cara (proses) pencatatan yang dimulai dengan pemberitahuan kehendak melangsungkan perkawinan, pelaksanaan akad nikah di hadapan pegawai pencatat nikah dan dihadiri oleh dua orang saksi, penandatanganan akta perkawinan oleh kedua saksi, pegawai pencatatan dan wali.

Dalam Kompilasi Hukum Islam (KHI) Pasal 7 ayat (1), di Indonesia disebutkan, tujuan pencatatan perkawinan yang dilakukan dihadapan dan di bawah pengawasan Pegawai Pencatat Nikah adalah untuk terjaminnya ketertiban perkawinan. Namun ditegaskan perkawinan yang dilakukan di luar pegawai pencatat nikah tidak mempunyai kekuatan hukum, dan perkawinan hanya dapat dibuktikan dengan akta nikah yang dibuat oleh pegawai pencatat nikah.

Dari teks-teks perundang-undangan Indonesia, yang berbicara tentang pencatatan perkawinan tampak bahwa fungsi pencatatan hanya sekedar urusan administrasi, bukan sebagai syarat sah atau tidaknya pernikahan (akad nikah). Namun kalau teks-teks tersebut dihubungkan dengan pasal-pasal lain yang ada dalam batang tubuh UU khususnya UU No. 1 tahun 1974 secara keseluruhan, dan dihubungkan dengan peraturan perundang-undangan lain yang pernah berlaku di Indonesia, ternyata timbul pro dan kontra tentang fungsi pencatatan. Sebagian memandangnya sebagai syarat administrasi. Sementara yang lain pemikir berpandangan, pencatatan menjadi syarat sah.

\section{PENCATATAN NIKAH MENJADI SYARAT SAH DALAM KAJIAN MASLAHAH}

Pernikahan bukan hanya mengikat hubungan antara suami dan isteri, tapi menimbulkan ikatan yang sangat luas tidak hanya pada pelaku pernikahan tersebut melainkan juga anak-anak akibat pernikahan, keluarga, masyarakat dan negara. Dengan demikian, pernikahan tidak dianggap selesai dengan hanya terjadinya akad nikah, itu sejalan dengan perubahan sosial dan perkembangan hukum Islam dalam format perundang-undangan hukum keluarga di Indonesia, maka pencatatan perkawinan merupakan pembaharuan hukum Islam demi 
tertibnya administrasi keluarga dan kependudukan, hal ini penting karena hukum keluarga dianggap sebagai inti syari'ah dan dipandang sebagai pintu kemaslahatan (Khoisi'yah, 2015:200).

Kemaslahatan dalam pencatatan nikah sebagai syarat administrasi selama ini belum mewujudkan ketertiban perkawinan dan membawa kepada kemudharatan pelaku nikah siri itu sendiri. Pencatatan merupakan bentuk pengakuan dan jaminan hak dalam perkembangan masyarakat, kemajuan administrasi, dan ketatanegaraan. Ketika dihubungkan dengan nikah siri yang tidak dilakukan pencatatan oleh Pegawai Pencatat Nikah, maka tidaklah menjadi sebuah bukti yang diterima oleh masyarakat dan pemerintah. Bentuk jaminan dan pengakuan di masa sekarang muncul dalam bentuk tulisan (hitam di atas putih). Dengan ungkapan lain, pada masa ulama fuqaha terdahulu, konteks dari publikasi sebagai sarana pengakuan dan jaminan dalam masyarakat komunal adalah terbiasa dengan lisan. Sementara konteks dari publikasi pengakuan dan jaminan hak pada zaman sekarang adalah tertulis.

Kemaslahatan dari publikasi tertulis dengan dokumentasi yang resmi termasuk dalam al-umūru dharūriyah yaitu pemeliharaan hak-hak suami isteri dan hak-hak anak, seperti garis keturunan, nafkah dan lain sebagainya, dan penetapan semua itu di kala terjadi konflik dan pengingkaran, serta pemeliharaan hubungan suami isteri dari terpaan keragu-raguan, kecuriagaan dan prasangka buruk. Seluruh perkara ini (pemeliharaan akan semua perkara di atas) akan terwujud dengan persaksian saksi-saksi, pemberitahuan umum tentang pernikahan, publikasinya melalui acara pesta dan walimah (ad-Duraiwisy, 2010:100), serta acara-acara lain yang serupa, dalam bentuk yang lebih sempurna lagi mendapatkan sertifikasi dari pihak yang berwenang pada saat ini. Maka sudah menjadi kewajiban apabila terjadi perubahan hukum karena disebabkan berubahnya zaman dan keadaan serta pengaruh dari gejala-gejala kemasyarakatan itu sendiri. Hal itu sesuai dengan kaidah yang berbunyi"Suatu 
ketetapan fatwa (hukum) dapat berubah disebabkan berubahnya waktu, tempat, dan situasi" (Al-Mawardi, tt: 3).

Kaidah ini menetapkan suatu prinsip bahwa pemerintah harus mempunyai kemampuan melihat kemaslahatan sosial yang mungkin berubah dan berbeda karena perubahan zaman dan perbedaan tempat. Karena pemerintah berperan untuk melindungi agama serta mengatur urusan keduniaan. Dengan demikian, secara sederhana kemaslahatan dalam pencatatan pernikahan dapat dinyatakan sebagai meraih semua kebaikan untuk manusia yang diatur oleh pemerintah dengan berdasarkan kemaslahatan serta mencegah semua keburukan yang sesuai dengan syari'ah. Landasan metodelogi secara al-mashlahat al-mursalah, menjadikan pencatatan perkawinan dengan status hukum yang jelas, maka berbagai macam bentuk kemudharatan seperti ketidakpastian status bagi wanita dan anak-anak akan dapat dihindari.

Isteri dan anak dari nikah siri tidak dapat menuntut hak-haknya melalui pengadilan apabila terjadi perceraian. Baik hak nafkah, tempat tinggal, warisan dan gono gini dari suaminya. Adapun hak anak, hanya mempunyai hubungan perdata dengan ibunya. la tidak bisa menuntut hak nasab, nafkah, hak waris, pemeliharaan dan pendidikan atas harta peninggalan bapaknya (Prihatin, 2009: 175).

Bahkan Dampak Nikah Siri adalah Berselingkuh menjadi hal yang wajar, Banyaknya timbul poligami yang terselubung, Pelecehan seksual terhadap kaum hawa dikarenakan sebagai pelampiasan nafsu sesaat yang apabila telah terjadi pihak perempuan sangat dirugikan, sehingga timbulah penyesalan, hawa nafsu selama ini mengebu-gebu menjadi hilang, dan pikiran jernih justru mendatangi mereka. Karena akibatnya kebanyakan suami lari dari tanggung jawab (Jaya, 2017: 23). Karena pihak isteri sewaktu-waktu dapat diceraikan suaminya atau sebaliknya pihak suami sewaktu-waktu dapat berpoligami tanpa izin isteri pertama. Suami bahkan dapat mengingkari perkawinan dan anak-anak hasil nikah siri tersebut. 
Sedangkan isteri tidak mempunyai bukti-bukti yang berkekuatan hokum untuk melawan di pengadilan. (Faiza \& Rahman, 2014:49)

Adapun dampak nikah siri terhadap pernikahan poligami berdasarkan fakta di lapangan adalah negatif karena pelaku suami lebih suka mengabaikan aturan daripada mematuhinya karena alasan hukum dan faktor non-hukum seperti agama, ekonomi, sosial dan psikologi. Akhirnya melekatkan stigma negatif pada suami dan istri kedua seperti dipahami bahwa istri pertama dan anak-anaknya yang dianggap sah karena mereka dicatat secara hukum sementara yang lain tidak sah karena tidak dicatat (Rasmawati \& Abu Bakar, 2019:206).

Pemerintah melalui pendekatan maslahah juga dapat menutup dampak dan kemudharatan nikah siri agar masyarakat tidak kena dampak yang merugikan. Ini sesuai dengan kaidah fiqh: "Menghindari kerusakan harus lebih diutamakan dari meraih manfaat". (al-Nadwi, 1994:207). Dapat dipahami dalam kaidah ini juga, pemerintah harus membuat kebijakan politik dan perundang-undangan sesuai dengan skala prioritas. Kalau dalam suatu masalah terdapat dua hal yang bertentangan, di satu sisi menguntungkan tapi pada sisi lain menimbulkan kemafsadatan, maka yang harus didahulukan adalah prinsip menghindari kemafsadatan. Pemerintah ingin menghindari korban dari pada nikah siri ini. Maka wajib bagi rahyat untuk taat kepada pemerintah. "Hai orang-orang yang beriman, taatilah Allah dan taatilah Rasul (Nya), dan ulil amri (pemerintah) di antara kamu" (QS. 4: 59). Dan juga merujuk pada sabda Rasulullah: "kewajiban seorang muslim adalah mendengarkan dan taat (kepada pemimpin) dalam hal persoalan yang dia sukai dan yang dia benci, kecuali jika diperintahkan melakukan maksiat. Apabila dia diperintahkan berbuat maksiat, maka tidak ada kewajiban mendengarkan dan taat". (Al-Bukhari, tt: 1497)

Taat kepada ūlil amri jelas wajib dilaksanakan sejauh tidak bertentangan dengan agama. Hal ini sesuai dengan kaidah fiqh:"Kebijakan imām tergantung pada kemaslahatan rakyat" (Al-Suyuti, 2004:278). Maksud dari kaidah ini adalah tindakan pemerintah terhadap rakyat hendaklah berdasarkan kemaslahatan 
ummah. Dalam kaidah tersebut, segala tindak-tanduk pemerintah terhadap rakyatnya hendaklah berlandaskan kemaslahatan dan kemanfaatan rakyat, bukannya kepentingan pemerintahan semata-mata. Pengakuan resmi (penulisan akad) dengan arti tercatat resmi dikantor catatan sipil adalah perkara yang diwajibkan oleh undang-undang, untuk menjaga akad ini dari pengingkaran dan penipuan setelah dilaksanakannya, baik itu dari pihak suami-istri atau pihak lain.

Pemerintah sebagai pengganti fungsi kenabian dalam menjaga agama dan mengatur dunia wajib berdasarkan rasio. Karena rasio manusia mempunyai kecenderungan untuk menyerahkan kepemimpinan kepada pemimpin yang dapat menghalangi terjadinya kezaliman yang menimpa rakyat serta menuntaskan perselisihan dan permusuhan di antara rakyatnya. Seandainya tidak ada pemimpin dan pemerintah niscaya mereka akan hidup dalam ketidakteraturan tanpa hukum dan menjadi bangsa yang primitif tanpa ikatan (al-Mawardi, 2000:15).

Pembahasan lebih luas, di kalangan pemikir telah dibicarakan tentang status pencatatan perkawinan. Di antara mereka adalah Ahmad Safwat, seorang sarjana Mesir dan sekaligus tulisan beliau ini dimaksudkan sebagai bahan masukan dalam upaya pembaharuan hukum keluarga Mesir. Safwat mengharuskan pencatatan perkawinan berdasar pada pemikiran, bahwa ada hukum yang mewajibkan perilaku tertentu, dan mestinya hukum ini tidak berubah, kecuali hanya dengan perubahan tersebut tujuan hukum dapat dicapai dengan tepat guna (efisien). Artinya kalau ada langkah yang lebih efisien untuk mencapai tujuan, langkah itulah yang lebih diutamakan. Kehadiran saksi dalam akad nikah menurut Ahmad Safwat, bertujuan sebagai pengumuman kepada khalayak ramai. Kalau ada cara yang lebih baik atau lebih memuaskan untuk mencapai tujuan tersebut, cara ini dapat diganti yakni dengan pencatatan perkawinan secara formal. Dengan ungkapan lain, pencatatan perkawinan bagi Safwat sebagai ganti kehadiran saksi, sebuah rukun yang harus dipenuhi untuk sahnya akad nikah (Nasution, 2009:359). 
Adapun tujuan pencatatan perkawinan menurut Shaltut adalah untuk memelihara hak-hak dan kewajiban para pihak dalam perkawinan, yakni hak-hak pihak suami/isteri dan anak-anak atau keturunan, seperti pemeliharaan dan warisan. Pencatatan ini sebagai usaha mengantisipasi semakin menipisnya iman orang Muslim yang semakin banyak terjadi pengingkaran-pengingkaran janji yang mengakibatkan dalih untuk lari dari kewajiban. Karena ukuran iman itu adalah sesuatu yang tersembunyi (abstrak), salah satu jalan keluar sebagai usaha prefentif agar orang tidak lari dari tanggung jawab membuat bukti tertulis (Shaltut, tt: 271).

Quraish Shihab mencatat, semua ulama sepakat tentang larangan merahasiakan perkawinan berdasarkan perintah Nabi untuk menyebarlauskan berita perkawinan. Adapun perkawinan tanpa pencatatan (di bawah tangan), dalam konteks Indonesia, dapat mengakibatkan pelanggaran ketentuan yang ditetapkan oleh pemerintah dan DPR. Sedangkan al-Qur'ān memerintahkan untuk mematuhi (taat) kepada ulil amri selama tidak bertentangan dengan hukumhukum Allah. Sementara perintah pencatatan perkawinan bukan hanya tidak bertentangan, tetapi sejalan dengan semangat al-Qur'an (Shihab, 1996: 204).

Sebagian ulama dan para penulis kontemporer, termasuk Yusuf Ali athThanthawi, Yusuf al-Qardhawi dan lain-lain berpandangan wajibnya persoalan sertifikasi pernikahan secara tertulis dan pendataannya dengan resmi. Barang siapa tidak mendaftarkannya berarti telah berbuat dosa dan dikenakan sanksi dengan hukuman yang ditetapkan oleh waliyul amr (penguasa), meskipun akad nikahnya (tetap) sah jika tidak disertai sertifikasi. (ad-Duraiwisy, 2010:97) Dalil mereka adalah:

1.Berguna untuk menetapkan hak-hak dan hukum-hukum suami isteri, memelihara hak-hak anak, terutama di masa sekarang ini kerusakan telah merajalela, fitnah-fitnah semakin banyak, dan tanggung jawab orang telah hilang. Akan tetapi, perlu disampaikan kepada mereka bahwasanya 
JURISPRUDENSI:

Jurnal IImu Syariah, Perundang-undangan dan Ekonomi Islam

Volume 12 Edisi 1 Tahun 2020, 44-63

Doi: https://doi.org/ 10.32505/jurisprudensi.v12i1.1508

persoalan isyad (mempersaksikan) kepada khalayak dan sosialisasi sudah memadai untuk merealisasikan tujuan tersebut.

2.Bahwa waliyul amr (penguasa) sudah mengeluarkan kebijakan tentang sertifikasi dan menetapkannya dan taat kepada waliyul amr merupakan kewajiban. Berdasarkan firman Allah dan Sunnah Rasulullah.

Dalam konteks ini, Muhammad 'Aqlah mengatakan, sesungguhnya pandangan Islam secara prinsipil tidak mengharuskan satu bentuk simbolis tertentu untuk menyempurnakan akad nikah. Akad pernikahan ini sebagaimana seluruh akad-akad lainnya yang terselesaikan dengan ijab dan qabul (serah terima). Eksistensi dan kelangsungan tidak tergantung pada bukti tertulis. Bahkan persaksian orang sudah cukup untuk menguatkannya, baik persaksian yang berhubungan dengan akad itu sendiri dan impillikasinya seperti mahar kawin, nafkah, dan hak-hak lainnya (ad-Duraiwisy, 2010:98).

Hanya saja, esensi ini tidak berarti menghalangi diterbitkannya aturanaturan formal atau aturan administratif yang berorientasi pada pemeliharaan hakhak suami isteri dan kemaslahatan-kemaslahatan akad nikah. Sebagaimana juga tidak kontradiktif dengan penetapan kebijakan yang dipandang oleh pemerintah selaras dengan dinamika modernisasi dan menempuh cara-cara yang mutakhir dalam pembukuan dan pendataan. Dalam hal ini Abdul Fattah 'Amr menyatakan "pengetatan soal pendataan akad nikah termasuk dalam bingkai siyāsah syar'iyah (hukum tata negara secara syar'i) yang memungkinkan penguasa memaksakan regulasi itu pada rakyatnya karena pertimbangan kemaslahatan dalam hal tersebut (ad-Duraiwisy, 2010:100).

Dengan demikian, patut diduga bahwa pencatatan perkawinan yang diamanatkan oleh UU No. 22 Tahun 1946 dan UU No. 1 Tahun 1974, dapat dijadikan akar intelektualnya bersumber pada UU Perkawinan Mesir Tahun 1931. Secara historis, Mesir pada tahun 1931 (jauh sebelum UU No. 22 Tahun 1946 tentang Pencatatan Perkawinan, Talak, dan Rujuk disusun dan diberlakukan), 
telah terbentuk UU perkawinan. Salah satu kandungannya adalah perkawinan yang diakui adalah perkawinan yang dibuktikan dengan akta perkawinan resmi (Mubarok, 2005:60).

Sujari Dahlan mencoba mendukung pencatatan perkawinan dengan kemaslahatan sebagai alasannya, serta menggunakan tiga kaidah: pertama, kaidah maslahat itu sendiri, yaitu peroleh manfaat dan antisipasi atau penolakan terhadap kerusakan. Kedua, kaidah sadd adz-dzari'ah. Ketiga, pencatatan perkawinan sebagai salah satu bentuk interaksi antara fiqh Islam dengan perkembangan masyarakat akibat dari perubahan (taqhayyur al-ahkām bi taghayyur al-azmān wa al-makān) (Dahlan, 1996:40).

Berdasarkan pembahasan pandangan para pemikir kontemporer tersebut dapat disimpulkan, bahwa dalam membahas pencatatan perkawinan para pemikir kontemporer secara umum menekankannya dengan keharusan pada fungsi dan tujuannya, yakni sebagai sarana pengumuman dan bukti terjadinya transaksi (akad nikah). Sebagai sebuah transaksi, akad nikah tentu melahirkan akibat-akibat hukum di antara para pihak maupun keturunan yang lahir dari perkawinan kelak. Tujuan dan fungsi saksi dalam hal ini adalah untuk menjamin hak dan tanggung jawab pihak-pihak dalam perkawinan. Fungsi dan tujuan inilah yang dikontekskan pemikir kontemporer dalam bentuk pencatatan, tidak cukup hanya saksi oral, seperti tuntutan masa lalu ketika masyarakatnya masih masyarakat komunal, tetapi harus dalam bentuk tertulis.

Maka perlu keberanian para ulama untuk memasukkan pencatatan perkawinan sebagai salah satu rukun perkawinan ala fiqh Indonesia, agar jelas status perkawinan yang tidak dicatatkan merupakan perkawinan yang tidak sah sehingga masyarakat muslim Indonesia akan lebih berhati-hati dalam menyikapinya (Ma'sum, 2013: 212). Fakta lain menunjukan fiqh Indonesia tertinggal dengan fiqh Negara tetangga Malaysia. Undang-undang Malaysia berkenaan dengan pencatatan perkawinan, bahwa sanksi hukuman bagi mereka yang tidak mencatatkan perkawinannya lebih tegas pada sistem hukum keluarga 
Malaysia dibanding Indonesia. Denda sekitar 1000 ringgit dan pidana kurungan penjara 6 bulan akan mengancam bagi mereka yang tidak mencatatkan perkawinannya. Sementara di Indonesia hanya Rp. 7500, tidak ada sanksi kurungan sesuai dengan pasal 45 PP nomor 9 tahun 1975 tentang peraturan pelaksanaan UU no 1 tahun 1974 (Siddik, 2017:135).

Pola hukum Islam yang diterapkan di Malaysia, kemudian diikuti oleh Kesultanan Brunei. Beberapa pasal yang tercantum dalam hukum keluarga Brunei, secara umum memiliki kesamaan dengan prinsip-prinsip yang terdapat dalam hukum keluarga Malaysia. Pencatatan perkawinan merupakan salah satu bentuk reformasi hukum keluarga yang dilakukan oleh negara-negara Muslim di dunia. Tujuannya adalah agar tercapainya kepastian hukum, ketertiban hukum, dan perlindungan hukum atas suatu perkawinan. Oleh karena itu, berbagai negara di dunia Islam menjadikan pencatatan perkawinan sebagai suatu kewajiban yang dilegalkan dalam suatu perundang-undangan (Mustika, 2011:63). Dapat dipahami bahwa Hukum pencatatan perkawinan yang diberlakukan di Negara Muslim, lebih berat dan tegas bahwa pencatatan perkawinan berpengaruh terhadap keabsahan (validitas) suatu perkawinan. Dengan demikian, pencatatan perkawinan bukan sekedar persyaratan administratif saja.

\section{SIMPULAN}

Setelah mengkaji dan meneliti tentang nikah siri dari berbagai aspeknya serta dengan melihat fakta-fakta kekinian, maka penulis mencoba menyimpulkan pemerintah dengan pendekatan maslahah dapat menetapkan pencatatan sebagai syarat sah nikah. Dengan demikian, Pemerintah dapat memasukan pencatatan nikah dalam revisi undang-undang perkawinan No. 1 Tahun 1974. Pencatatan nikah pada saat ini menjadi publikasi atau bukti autentik yang dapat membenarkan adanya nikah seseorang serta untuk melindungi hak dan kewajiban orang-orang terkait, seperti perlindungan terhadap keturunan, harta, jiwa, dan lain-lain. 


\section{DAFTAR PUSTAKA}

ad-Duraiwisy, Yusuf. 2010. Nikah Siri, Mut'ah \& Kontrak dalam timbangan alQur'ān dan as-Sunnah, Jakarta: Darul Haq.

Al-Ghazali, Abu Hamid Muhammad Bin Muhammad Bin Muhammad. Tt. alMustasyfā min 'Ilmi al-Ushul, Mesir: Sayyid al-Husein. al-Khalaf, Abd Wahab. 1977. al-Siyāsah al-Syar'iah, Kairo: Dār Anshar. al-Mawardi, Abu al-Hasan 'Ali Ibn Muhammad Ibn Habib al-Basri al-Baghdadi. Tt. al-Ahkam al-Sultaniyyah wa al-Wilāyah al-Diniyyah. Beirut: Dār al-Kutub al- 'I1miyyah.

al-Mawardi, Imam. 2000. Hukum Tata Negara dan Kepemimpinan dalam Takaran Islam, diterjemahkan oleh Abdul Hayyie al-Kattani dari al-AhkaamusSulthaniyyah wal-Wilāyātud-Dīniyyah, Jakarta: Gema Insani Press. al-Nadwi, 'Ali Ahmad. 1994. al-Qawā'id al-fiqhiyyah, Damaskus: Dar al-Qalam. al-Salam, Izzudin Bin 'Abd. 1990. Qawā'id al-Ahkam fi Mashālih al-Anam, J.2, Mesir: Dār al-Ma'arif.

Al-Suyuti, Jalal al-Din 'Abd al-Rahman b. Abi Bakr. 2004. al-Asybah wa al-Naza'ir fi Qawa'id wa Furu' al-Syafiiyyah, juz.l, Qaherah: Dar al-Salam.

Al-Syathibi, tt. al-Muwafaqat fi Ushul al-Ahkam, tt,: Dar al-Fikr.

al-Syatibi, Abu Ishaq Ibrahim Bin Musa Ibn Muhammad al-Lakhmi. 1994. alMuwafaqat, juz. III, Beirut: Dār al-Fikr.

al-Yasu'î, Al-Ab Luwis Ma'lūf. Tt. al-Munjid fi al-Lugah wa al-Adab wa al-'Ulūm, Beyrūt: Matba'ah al-Katulikiyyah.

al-Zuhaili, Wahbah. 1969. al-Wasith fi Ushul al-Fiqh, Dimasyqi: al-Mathba'at al'Ilmiyyah.

Asy-Syathibi, tt. al-Muwafaqat Ushūl al-Syari'ah, jilid II, Mekkah: Dār al-Baz.

Burhanuddin, 2010. Nikah Siri, Menjawab Semua Pertanyaan Tentang Nikah Siri,

Yoyakarta: Pustaka Yustisia. 
Dahlan, M. Sujari. 1996. Fenomena Nikah Siri: Bagaimana Kedudukanya Menurut Hukum Islam, Surabaya: Pusaka Progresif.

Djamil, Fathurrahman. 1997. Filsafat Hukum Islam, Jakarta: Logos Wacana Ilmu.

Djazuli, 2003. Fiqh Siyasah, Implementasi Kemaslahatan Umat dalam RambuRambu Syari'ah, Jakarta: Prenada Media.

Engneer, Asghar Ali. 1994. Hak-Hak Perempuan dalam Islam, Yogyakarta: Bentang.

Et al, Juraeri Tahir. 2017.“Faktor-Faktor Penyebab Nikah Siri Di Sulawesi Barat”, Jurnal Diskursus Islam, Vol. 5, No 2.

Faiza \& Rahman, Faiz dan Rizka Nur. 2014. "Perkawinan Siri Online Ditinjau Dari Perspektif Hukum Perkawinan Yang Berlaku Di Indonesia", Jurnal Penelitian Hukum, No. 1.

Instruksi Presiden R.I. Nomor 1 Tahun 1991, Kompilasi Hukum Islam di Indonesia, (Departemen Agama R.I. Direktorat Jenderal Pembinaan Kelembagaan Agama Islam, 1997/1998)

Jaya, Dwi Putra. 2017. "Nikah Siri Dan Problematikanya Dalam Hukum Islam", Jurnal Hukum Sehasen, Vol.2, No.2

Khallaf, Abdul Wahab. 1987. Masadir Al-Tasyri' Fi Ma La Nas Fih, Cairo: Maktabah Da'wah al-Islamiyyah.

Khosyi' ah, Siah. 2015. “Akibat Hukum Perkawinan Tidak Dicatat Terhadap Istri Dan Anak Atas Hak Kebendaan Menurut Hukum Islam Di Indonesia" AsySyari'ah Vol. 17 No. 3.

Ma'sum, H. Endang Ali. 2013.“Pernikahan Yang Tidak Dicatatkan Dan Problematikanya", Musâwa, Vol. 12, No. 2.

Ma'u, Dahlia Haliah. 2016. "Nikah Sirri dan Perlindungan Hak-Hak Wanita dan Anak(Analisis dan Solusi dalam Bingkai Syari'ah)", Jurnal Al-Ahkam, Vol 1, No. 1.

Manzūr, Ibn. 1994. Lisān al 'Arab, Juz II, Beyrūt: Dār Sādir. 
Mubarok, Jaih. 2005. Modernisasi Hukum Perkawinan di Indonesia, Bandung: Bani Quraisy.

Mustika, Dian. 2011. "Pencatatan Perkawinan Dalam Undang-Undang Hukum Keluarga Di Dunia Islam", Inovatif, Jurnal IImu Hukum, Vol. 4.no. 5.

Nasution, Khoiruddin. 2009. Hukum Perdata Islam Indonesia dan Perbandingan Hukum Perkawinan di Dunia Muslim, Yogyakarta: Academia.

Prihatin, Farida. 2009. "Dampak Nikah Siri Terhadap Isteri Dan Anak", Jurnat Hukum dan Pembangunan Edisi Khusus Dies Natalis 85 T ahun.

Rasmawati, Shinta Dewi dan Abu Bakar, Muhammad Abral Bin Abu. 2019. "Polygamy Marriage: Legal Culture, Optional Political Identity and Marital Status Dilemma (A Case Study in Pekalongan)", Al-ihkam, Vol.14, No. 2.

Rohayana, Ade Dedi. 2008. “Qawā'id Fiqhiyyah dan Pengaruhnya terhadap perbedaan pendapat fuqaha", Disertasi UIN Sharif Hidayatullah, Jakarta, 2008.

Shaltut, Mahmud. Tt. al-Fatawa: Dirāsah al-Mushkilat al-Muslim al-Mu'asir fi Hayātil al-Yaumiyah al-Ammah, cet III, ttp, : Dar al-Qalam.

Shihab, M. Quraish. 1996. Wawasan al-Qur'ān: Tafsir Maudhu'i atas Pelbagai Persoalan Ummat, Bandung: Mizan.

Siddik, T. MA. Ibnu Ridwan, 2017. "Studi Pebandingan Ketentuan Pencatatan Perkawinan Di Indonesia Dan Malaysia", AL-MUQARANAH-Jurnal Program Studi Perbandingan Mazhab, Vol 5, No 1.

Zuhaili, Wahbah. Tt. adz-Zdarāi' fis Siyāsati Syar'iyah wa Fiqh Islamiih, Damaskus: Dārul Maktabi.

Zuhaily, Wahbah. 1989. al-Fiqh al-Islami wa Adillatuhu, Juz VII, Damsyiq: Dār alFikr. 